\title{
NOTES
}

\section{PROTECTION OF AUTOMOBILE INSTALLMENT BUYERS: THE FTC STEPS IN}

To INDUCE consumer purchases of automobiles "on time," dealers ' often conceal the high cost of installment plans. ${ }^{\perp}$ Car buyers can finance a purchase by cash payment with personal savings or borrowed funds, or by time payment in installments to the seller or his financing agency. ${ }^{2}$ Installment sales,

1. Installment buying is expensive. Consumers pay not only the cash selling price but also a time-sale markup. See note 4 infra. And in the absence of legal restraints, see note 2 infra, the markups have become exorbitant. See FTC, REPORT on MoToR VEnicte Industry 1065 (1939); Report of the State Banking Commission and Interum Advisory Legislative Committee to Investigate Finance Companies 67 (1935) (hercinafter cited as WISCONSIN REPORT); Note, Protection of Borrotuers in Distribution Finance, 60 Y AlE L. J. 1218, 1222 n. 15 (1951). See further, Findings and Declarations of Policy, Motor Vehicle Sales Finance Act, PA. Stat. Ann. tit. 69, \$602 (Cum. Supp. 1950).

On the other hand, advantages of the installment plan include: (1) permitting consumers to use goods while paying for them; (2) committing consumers to disciplined saving; (3) enabling retailers to increase sales; (4) providing sellers and financiers with a lucrative form of investment. See Evans, Consumer Credit Regulation in a Garrison Economy, 36 FED. Res. BuLL. 1437 (1950).

Nearly one half of new cars and more than one half of used cars were sold on the installment plan in 1949. Consumer installment credit based on these sales totaled more than six billion dollars. Automobile Manufacturers Association, Thirtietil Edition of Automobile Facts \& Figures (1950), quoted by Circular of the Association of Better Business Bureaus, Inc., dated October 20, 1950, copy on file in Yale Law Library.

Installment buyers generally have low incomes. See 1950 Survey of Consumer Finances, 36 FED. REs. BuLl. 1441 (1950) (Tables 4, 11). The financial ignorance of installment buyers has fostered installment plan abuses. See WiscnNsin REPoRT 23, 40. Fifteen percent of those engaged in auto finance and sales have been held responsible for ninety-five percent of abuses in the field. Wrsconsin REPORT 4. See also Mors, State Regulation of Retail Instalment Financing-Progress and Problems, $23 \mathrm{~J}$. of Bus. U. OF CHI. 199, 201 (1950). But the result of these abuses has been termed "a public scandal" by Governor Dewey. See Backman, The Big Cheat 12 (manuscript on file in Yale Law Library; condensation published in Harper's Magazine, Oct. 1948, p. 105). And according to the Boston Better Business Bureau, "in 1947, as a conservative estimate, $\$ 30,000,000$ was being exacted from the public by 'packing' the finance charges on automobile time payment contracts." See Memorandum from Bureau of Trade Practice Conferences and Wool Act Administration of the Federal Trade Commission, dated February 15,1950 , copy on file in Yale Law Library.

For historical, economic, and legal aspects of installment selling generally, see Berger, Usury in Instalment Sales, 2 LAw \& Contens. Prob. 148 (1935); Mors, Slate Reguldtion of Retail Instalnent Financing-Progress and Problems, 23 J. OF Bus. U. of CHI. 199 (1950), 24 id. 43 (1951); Note, Protection of Borrowers in Distribution Fintance, 60 YALE L. J. 1218 (1951).

2. Consumers may finance cars through: (1) retail sale credit, extended by the seller or his assignee, usually a sales finance company; (2) money or cash credit, extended by 
however, bring the dealer greater profits than sales for cash. ${ }^{3}$ To retain this lucrative trade, sellers by two devices deceive consumers: the time sale markup, compensating the financier for credit and risk, is disclosed only long after the car buyer has signed a conditional sales contract with finance charge columns left in blank ; or the seller discloses only a single combined markup that lumps together the cost of insuring the car with the credit charge for financing the time purchase. Both methods keep the buyer ignorant of the installment plan's cost until after he has obligated himself to pay; the second enables unscrupulous dealers to persuade buyers that "costly" insurance coverage, equally indispensable to the buyer's protection in a sale for cash, constitutes the bulk of the lumped markup. ${ }^{0}$ Thus consumers regard installment buying as costing little more than a purchase for cash. And shielded by consumer ignorance, dealers may exact exorbitant charges with small fear of timely detection. ${ }^{7}$

Sales finance company practices ${ }^{8}$ frequently encourage dealers to "pach" finance charges and veil the cost of installment plans. If a dealer's capital

a third party as an installment loan repayable on an installment payment b3sis; (3) money or cash credit, extended by a third party as a single payment loan repayable at a stated time and in a single payment. As to wholesale inventory credit, see note 10 infra. Installment loan credit is extended by commercial banls, small loan companies, industrial banks, industrial loan companies, credit unions, and miscellaneous lending groups. Hub3chek, The Drift Tourard a Consumer Credit Code, 16 U. of CHI. L. REv. 609, 611 (1949).

Usury laws generally place ceilings on money or cash credit, but permit larger rates of return for smaller loans. See Note, 60 YALE L. J. 1218,1218 n.1, 1225 nn.24-5 (1951). Retail sale credit, on the other hand, is not considered a "money loan" and thus is generally free from usury controls. Id. at $1218 \mathrm{n} .2$; Mors, supra note 1 , at 200.

For comparison of the total amount of each type of credit extended from 1929 to 1949 , see Legislation, 63 HARv. L. REv. 874 (1950); note 37 infra. See further Hubachel:, supra, at $613 \mathrm{n}$. \&. For comparison of the volumes of cash and credit sales of automobiles, see note 1 supra.

3. Cash sales net the seller only his retail markup. Time sales, on the other hand, yield an additional profit. Most auto dealers do not finance their own time sales, but assign time sale contracts to external financiers and share in the financier's profit. See notes 9,11 infra.

4. "Someone must furnish the money to make up the difference between the price of the goods and the amount paid down. That someone is entitled to compensation for the use of his money and for assuming the risks of repayment and the reasonable expense of conducting a business." BAckMaN, op. cit, supra note 1 , at 1 .

5. See Memorandum, supra note 1; Wisconsin Refort 37-8.

6. For discussion of the "lumping" practice, see Wisconsiz Reporr 40; BAchirs:, op. cit. stipra note 1 , at $\mathrm{S}$. Sellers often misrepresent the coverage as well as the cost of insurance. See id. at 9; Wisconsin REPort at 47; Memorandum, sipra note 1. For summary of analogous deceptive techniques in the field of money or cash credit (note 2 susro), see Hubachek, supra note 2 , at 615 .

7. See BackMan, op. cit. silpra note 1, passim; FTC, ReFort on Motor VEmicue InDUSTRY 932, 1064-5 (1939). See further Note, 60 YaLE L. J. 1218, 1222 n.15 (1951).

8. Sales finance companies exert poweriul influences over installment sellers. In faet, "after World War I the initiative in determining the terms and conditions of retail in- 
resources are inadequate for direct credit extensions to installment customers, finance companies take up his installment contracts. ${ }^{9}$ And when dealers need inventory credit, companies may condition wholesale financing arrangements on dealers' assignment of retail installment paper. ${ }^{10}$ The companies, however, do not compete for the profitable installment contracts by reductions in consumer charges; instead, unknown to consumers, they compete with "kickbacks" to dealers. ${ }^{11}$ These rebates stimulate dealers to "pack"12 the

stalment financing transactions largely passed from the instalment seller to the finance company." Mors, supra note 1, at 203. For analyses of the close economic relationship between finance companies and retailers, see Note, 60 YALE L. J. 1218 (1951); Wisconsin REPORT 21-9. See further Moss, Sales Finance Company Operations in 1947. 34 FED. Res. BuLL. 781 (1948).

9. "[S]ales finance companies hold approximately seventy-five per cent of all automobile instalment sale paper originating with automobile dealers and discounted by such dealers. (Dealers themselves carry about $7 \%$ of these instalment sales contracts)." Address by Thomas W. Rogers, Executive Vice President of the American Finance Conference, at Purdue University, Octoben 30, 1950, copy on file in Yale Law Library. Sec further 、 Note, 60 Yale L. J. 1218, 1221 n. 11 (1951).

10. "[T] he evil of floor planning [supplying inventory under credit secured by trust receipts] is the general tendency to coerce dealers into financing sales through the finturce company who does the floor planning." Wisconsin REPORT 39. See generally Note, 60 Yale L. J. 1218 (1951); Oil City Motor Co. v. C.I.T. Corp., 76 F.2d 589 (10th Cir. 1935), noted, 35 Col. L. REv. 1322 (1935). See also notes 46, 47 infra.

Occasionally the charge for wholesale inventory finance becomes exorbitant, particularly in fields where goods may not be resold to consumers under conditional sales contracts. See Klett v. Security Acceptance Co., 223 P. 2d, 299 (Cal. App. 1950) (chargge for flooring furniture equivalent to $12 \%$ annual interest). For the futility of attempting to curb wholesale credit abuses by usury statutes, see Note, 60 YALE L. J. 1218 (1951).

11. See BACKMAN, op. cit. supra note 1, at 2, 7. Finance companies shave overheal expenses, not to reduce finance charges for the consumer's benefit, but to offer fatter rebates to retailers. Cavers, The Constmer's Stake in the Finance Company Code Controversy, 2 LAw \& Contexp. Pros. 200, 211 (1935). Only by the elimination of abuses such as the rebate will "competition between finance agencies ... reduce charges and rates to the lowest possible point consistent with good business." Wisconsin ReFORT 58. Rebates average between 15 and 25 per cent of the finance charge on both new and used cars. Mors, supra note 1 , at 56 . Originally merely compensating retailers for recourse liability on assigned installment contracts, rebates have become powerful competitive wcapons among sales finance companies. WISconsin RePort 34-5; Note, 60 YALE L. J. 1218, 1223 n. 16 (1951).

These rebates may be in addition to, or may be disguised as, retailer commissions for selling to the consumer insurance policies also supplied by the finance companies. In suits under state statutes regulating rebates, see note 20 infra, courts have split on whether insurance commissions paid to retailers are in fact a form of participation in the finance charge. Compare General Motors Acceptance Corporation v. Commissioner of Banks, 258 Wis. 56, 45 N.W. $2 \mathrm{~d} 83$ (1950) (insurance commissions paid by a wholly owned suthe sidiary of a finance company held actually part of dealer rebates paid by the parent), with Department of Financial Institutions v. Johnson Chevrolet Company, 228 Ind. 397, 405, 92 N.E. 2d 714, 717 (1950) (opinion that authority to regulate rebates was not authority to control commissions). Whether an insurance commission paid to dealers as part of an insurance transaction wholly separate from assignment of the installment con- 
finance charges in which they share. Assignment of installment contracts also enables dealers to rationalize non-disclosure of itemized charges: their computation purportedly is a complex operation requiring the companies' expert staffs. ${ }^{13}$ Moreover, finance companies may directly abet deception of consumers, supplying alternative rate charts for dealers to shuffle and display to unwary customers for best advantage. ${ }^{14}$

Statutes in several states aim to curb these dealer abuses in installment sales. ${ }^{15}$ Some legislatures invalidate form contracts if credit charges were not

tract can be treated as part of the rebate is not clear. See Wilkie, "Dealer Participation" Includes Insirance Commissions, 5 Quarterly Report of the Coniference on Persorial Finance Law 38, 40 (Spring 1951). Commissions from the sale of insurance unconnected with finance probably should be excluded from rebate limits in order to encourage dealers to make itemized disclosure of insurance and finance for the benefit of consumers. See notes 17,26 infra.

Insurance is used as an evasive device in money or cash credit transactions as well as retail sale credit transactions (see note 2 sipra): "[It] has become a popular feature in connection with installment credit, both because it provides protection to the lender and borrower in case the security is destroyed or the borrower dies and because it an be a source of an extra and hidden profit. The profit may come to the lender as a commission for selling the insurance or as a rebate of part of the premium or as a favorable experience rating.' When insurance is required for the purpose of obtaining a charge in addition to the maximum legal interest rate, it is a device to evade the law." Hubsehel, stipra note 2, at 620-1. See further Pollak, Foundation for Econosrrc Researce, Sarall LoAN Laws of the United States 25-6 (1949) ; Columbia Auto Loan Co., Inc. v. District of Columbia, 193 F.2d 34 (D.C. Cir. 1951), affirming 78 A.2d 857 (Alun. Ct. App. D.C. 1951) (finance company disguising interest as cost of insurance).

12. The term "pack" is sometimes used to mean an overcharge added to the marlup by retailers and retained by them, deceiving both the consumer and the finance company. See Wisconsin REPORT 36. "Packs" are also defined as secret rebates the finance company pays to the dealer out of an excessive finance charge. See BAckssi:, op. cit. supra note 1 , at 2 . Since in either case the consumer pays the overcharge, "pack" in this Note refers to any excessive mark-up.

13. See generally Backaran, op. cit. supra note 1, at 8 , 12; Gilmore, The Scetured Transactions Article of the Commercial Code, 16 LAw \& Coxtenr. Pros. 27, 38 (1951); Program and Briefs for the Twenty-Fourth Anvual Session of the Confremeice on Personal Finance Law 17 n. 1 (1951). For limited FTC recognition of this argument, see note 26 infra.

14. The Federal Trade Commission has "had reason to believe that ... some finance companies were ... supplying sellers with two or more different rate charts which the seller could utilize to his own best advantage and usually to the purchaser's financial disadvantage." Communication to Yale Law Joursal from Jas. M. Mfead, Chairman, Federal Trade Commission, dated November 6, 1951, on file in Yale Law Library (hereinafter cited as Comarunication froar FTC Chairatan). See further Memorandum, stpra note 1; Regulation By Conference, A Nea Concept of Gozernment, address by Lowell B. Mtason, Acting Chairman, Federal Trade Commission, before the Association of Better Business Bureaus, Inc., June 14, 1949, copy on tile in Yale Law Library; BAcsirn:s, of. cit. supra note 1, at 7. For analysis of the technique of deception by use of multiple rate charts and difficulty in attempting to control it, see Mors, sipra note 1, at 46-7.

15. States attack retail sale credit abuses largely by Retail Installment Sales Acts and Sales Finance Company Acts. As to the content of these statutes, see Mors, supro 
filled in before the consumer signed. ${ }^{10}$ These and other statutes also demand pre-sale itemized disclosure of finance and insurance charges. ${ }^{17} \mathrm{~A}$ few laws,

note 1; Donaldson, An Analysis of Retail Installment Sales Legislation, 19 Rockr MT. L. REv. 135 (1947); Regulation of Retail Installment Sales: New Statute in Ohio, 63 HARV. L. REv. 874 (1950); notes 16-23 infra. Abuses in the field of money or cash credit have been left largely to usury and Small Loan statutes. See generally, Hubachek, supra note 2; Foster, The Personal Finance Business under Regulation, 8 Law \& Contrim. Proв. 154 (1941) ; Bogert, The Future of Small Loan Legislation, 12 U. of Cmr. L. Rev. 1 (1944). As to the futility of curbing sales credit abuses by usury statutes, sce Note, Protection of Borrowers in Distribution Finance, 60 YALE L. J. 1218 (1951).

In addition to containing disclosure and rate control provisions, many statutes prohibit miscellaneous installment sale abuses, including, among others: packs added by the seller for his own benefit (see note 12 supra), Rule I(B) (1), WIs. ADMIN. ORders 116 (Red Book 1944); refund of less than a required amount of the finance charge in case the consumer accelerates payment; repossessing in case of default in other than authorized manner; forcing buyers to take out insurance; failure to provide a copy of the insurance policy; charging more than permissible rate for delinquency and repossession charges; coercion of retailers by finance companies or manufacturers to secure assignment of installment sales contracts. See generally Legislation, 63 HARV. L. REv. 874 (1950). Violation of the statutes may result in loss of license. See, e.g., Wis. STAT. $\$ 218.01(3)$ (1949). Dealer licenses are required by Pennsylvania, Virginia, and Wisconsin. Sales Finance Companies need licenses in Colorado, Connecticut, Indiana, Maine, Maryland, New Jersey, Pennsylvania, and Wisconsin. An attempt by Indiana to prohibit local retailers from assigning contracts to out of state (unlicensed) finance companies, sec IND. AnN. Stat. \$58-909 (Burns 1943), was declared unconstitutional in Department of Financial Institutions v. General Finance Corporation, 227 Ind. 373, 86 N.E. 2 d 444 (1949). Furthermore, violations may result in pecuniary penalties. See, e.g., Car. Crv. CODE $\$ 2982$ (c) (e) (Supp. 1951) (conditional sale contract not enforceable if time price markup exceeds legal limit; buyer can recover total amount paid on the balance duc under the contract). See further Carter v. Seaboard Finance Co., $33 \mathrm{Cal} .2 \mathrm{~d} \mathrm{564,} 203 \mathrm{P}$. $2 \mathrm{~d} 758$ (1949) (violation of $\$ 2982$ (a) requiring pre-sale disclosure renders contract unenforceable despite lack of specific penalty in this provision); Colo. Stat. ANN. $\$ 449$ (b) (Cum. Supp. 1951) (forfeiture of markup, delinquency or collection charges); Stride v. Martin, 184 Md. 446, 41 A.2d 489 (1949) (failure to give buyer a copy of contract entitles him to recover all payments and deposits). And offenders may be subject to finc or imprisonment. See, e.g., N.J. StAT. ANN. $\$ 17: 16 \mathrm{~B}-9$ (1950) ( $\$ 500$ fine if sales finance company operates without a license); PA. STAT. ANN. tit. 69, $\$ 637$ (Cum. Supp. 1950) ( $\$ 500$ for first violation, same plus one year imprisonment for subsequent violations).

16. See note 5 stipra. Use of installment sales contracts containing blank spaces to be filled in after contract execution is expressly prohibited by CoLO. STAT. ANN. c. 16, $\$ 446$ (a) (1) (Cum. Supp. 1951); Conn. Rev. STAT. \$1222b (Supp. 1951); ME. Rev. Stat. c. 56, §264-A (1951); Md. Anv. Code Gen. Laws art. 83, §118 (Cum. Supp. 1947); Pa. Stat. Ann. tit. 69, \$615(A) (Cum. Supp. 1950). See also note 25 infra.

17. See note 6 supra. Pre-sale itemization of insurance and finance charges is required by: Cal. Civ. Code $\$ 2982$ (Supp. 1951); ConN. Rev. Stat. §1223b (Supp. 1951) (but cf. $\$ 2402$, which permits lumping of insurance and finance charges on auto invoices and order forms); ME. Rev. Stat. c: 56, §264-A (1951); Md. AnN. Code Gen. Laws art. 83, $\S 117$ (a) (Cum. Supp. 1947); Pa. Stat. AnN. tit. 69, $\$ 614$ (Cum. Supp. 1950); Wis. STAT. $\$ 218.01(6)(b)$ (1949) (but cf. $\$ 218.01(6)$ (em) which allows lumping on Commissioner's approval if the dealer finances his own installment contracts). Cf. VA. Cove ANN. \$46-532 (1950) (requiring disclosure of separate items at time of delivery of the motor vehicle). 
on the other hand, ironically permit lumping of charges until long after consummation of the sale. ${ }^{18}$ Some states try to compensate for resultant consumer harm and clamp ceilings on finance charges ${ }^{10}$ and dealers rebates. ${ }^{20}$ But many statutes do not cover all consumer commodities, ${ }^{21}$ while some are limited to goods sold under a stipulated price. ${ }^{22}$ And significantly, two-thirds of the states have not enacted legislation to protect consumers from these abuses in installment selling. ${ }^{23}$

In an attempt to fill the gap in state legislation, the FTC, acting under the "unfair competition" provisions of the Federal Trade Commission Act,

18. See notes 6,7 supra. The following statutes expressly permit lumping for the period indicated, requiring itemization only at the end of that period. Colo. Srar. Az:2. c. 16, $\$ 446$ (b) (6) (Cum. Supp. 1951) (30 days); INd. ANn. Stat. \$ 5S-\$04 (Burns 1943) (25 days); MIAss. ANN. Laws c. 255, $\$ 12$ (Cum. Supp. 1948) (requires lumping, 20 days): Mitcr. Stat. Ann. $\$ 19.415$ (2) (Henderson 1951 Cum. Supp.) (25 days; $\$ 9.1482$, as amended, which inconsistently required pre-sale disclosure, sce People v. Dale H. Hughes, Inc., 321 Mich. 573 (1948), repealed in 1949) ; N.J. Sr.1T. Axw. § 17.16B-6(b) (6) (1950) (25 days) ; N.Y. Pers. Prop. Law $\$ 6+\mathrm{t}$ (g) (25 days); Onio Cone $\$ 6346-18$ (Page's 1951 Supp.) (25 days). As to Wisconsin, see note 17 supra.

Even Federal Regulation W, aimed at curbing inflation, though possibly once having the auxiliary purpose of correcting abuses, see Legislation, 63 Hanv. L. Rev. 874, 875 (1950), now specifically permits lumping, 32A Cone Fed. ReGs. c. XV, Reg. IV §6(2) (c) (4) (1950). For a conflicting federal regulation, see note 26 infra.

19. Ind. Ans. Stat. $\$ \S 58-906,58-926$ (Burns 1943) and Rule 58-926-1 thereunder, see Horack, 2 Ind. Adains. Cone 4403-4 (1941); Ohro Cone $\$ 6346-20$ (Page's 1951 Supp.). The Miassachusetts statute requires a legend on all conditional sales cuntracts to the effect that the finance charge is not regulated by law. Mass. Aws. Luws c. 255, $\$ 12 \mathrm{~A}$ (Cum. Supp. 1948). Of the states requiring pre-sale diselosure, Californiz and Pennsylvania also regulate finance charges. See CAL. CIr. Code $\$ 2982$ (c) (Supp. 1951); Pa. Stat. Anx. tit. 69, $\$ 619$ (Cum. Supp. 1950).

20. IND. ANs. STAT. $\$ 58-910$ (Burns 1943) and Rule 58-926-1, supra note 19; Wis. Stat. $\$ 218.01(5)$ (a) (c) (1949) and Rule II adopted thereunder, see Wrs. Anxrs:: Oroers 117 (Red Book 1944). See note 11 supra. Cf. Colo. Star. Axix. c. 4\$, §302(7) (Cum. Supp. 1951) ("Unfair Practices Act," prohibiting secret rebates to "certain purchasers" as destroying competition). Of the states that allow lumping until after the sale, Indiana regulates both the rebate and the finance charge; Colorado and Wissonsin regulate the rebate only; and Ohio regulates only the finance charge. See notes $18-9$ supro.

21. The following states limit coverage to sales of motor vehicles: California, Colorado, Maine, Michigan, Pennsylvania, Wisconsin.

22. Connecticut $(\$ 3,000$ or less $)$; Indiana $(\$ 2,500)$; MIaryland $(\$ 2,000)$; New Jersey $(\$ 3,000)$; New York $(\$ 1,500)$; Ohio (no limit).

23. The Uniform Conditional Sales Act, adopted by 12 jurisdictions, see 2 Unirarsis Laws Annotated 6 (Cum. Supp. 1951), does not deal with deceptive practices that enable sellers to misrepresent the cost of installment buying and pack time-sale marlups.

In addition to the state statutes discussed supra, see HawaIn REv. L.Iws \$\$9162, 9164 (1945) (requiring separate pre-sale disclosure of finance and insurance charges, and limiting former to legal amount of discount on comparable loans of money); Regulation for the Conduct of the Business of Licensed Motor Velicle Dealcrs in the District of Colum:bia (mimeo. 1951) (requiring pre-sale itemization of insurance and finance charges). 
recently promulgated regulations for protecting the installment buyer. ${ }^{24}$ For automobile installment sales in interstate commerce, the FTC rules compel pre-sale disclosure of markups, branding use of incomplete blank-space contracts an "unfair trade practice."25 Moreover, pre-sale itemization in writing of insurance and finance charges is directed. ${ }^{26}$ Violations subject offenders

24. Trade Practice Rules Relating to the Retall. Installment Sale and Financtng of Motor Vehicles, 16 Fed. Reg. 1059 (1951) (hereinafter citcd as Ruless). The rules were promulgated February 6,1951 after discussions in which industry members were invited to take part. See Memorandum, supra note 1; Federal Trade Commission Press Release, dated September 12, 1949, copy on file in Yale Law Library; Regulation by Conference, A Neze Concept of Government, address by Lowell B. Mason, supra note 14. They issued pursuant to the Commission's power under $\$ 5$ of the Federal Trade Commission Act, 38 Stat. 719 (1914), as amended 52 STAT. 111 (1938), 15 U.S.C. $\$ 45$ (a) (1946), "to prevent persons, partnerships, or corporations . . . from using unfair methods of competition in commerce and unfair or deceptive acts or practices in commerce."

The rules declare each of the following to be unfair trade practices: (RULE I) false, misleading, or deceptive statements concerning insurance or finance generally; (RULE 2) failure to itemize costs before the sale; (RULE 3) use of installment sales contract with blank spaces to be filled in after execution; (RULE 4) use of rate charts to deceive as to the amount of the finance charge (specifically directed against the use of multiple rate charts, supra note 14, see Communication From FTC Chairman); (RuLe 5) requiring purchase of insurance as a condition to sale or financing. The rules arc limited to the sale of Motor Vehicles. See note 21 supra.

For general discussion of the scope and effect of the rules, see FTC "Auto Pack" Rules Interpreted, 5 Quarterly Report of the Conference on Personal Finance LAw 34 (Spring 1951). The FTC met considerable opposition when the rules were proposed. See Mors, supra note 1, at 207. The same opposition greeted a proposal in an early draft of the Uniform Commercial Code to require pre-sale itemization of insurance and finance charges. See Gilmore, The Sectured Transactions Article of the Commercial Code, 16 LAw \& Contemp. ProB. 27, $37-8$ (1951). For a striking illustration of the need for Federal intervention in the field, see Department of Financial Institutions v. Gencral Finance Corporation, 227 Ind. 373, 86 N.E. $2 d 444$ (1949) (state's attempt to make regulation of local finance companies effective by prohibiting local dealers from assigning to foreign, unlicensed finance companies held unconstitutional).

25. Rule 3, supra note 24. See note 5 supra.

26. Rule 2, supra note 24 . See note 6 supra.

The FTC's only concession to finance company and retailer arguments against the presale disclosure requirement, viz., that the seller cannot be expected to handle complicated insurance manuals and rate charts separately prior to each sale, is a provision allowing the disclosed insurance premium to be based partly on an estimate when its computation is too complex for the retailer. But he must inform buyers that the markup is bascd ont an estimate and compensate for overcharges before the last installment is paid. See RuLE 2 (II) (d) n.2.

The seller/finance company argument rests on shaky grounds. Some states have long required pre-sale itemization without apparent interference with retail installment selling. Significantly, the standard contract form used by one of the largest finance companics in a state such as New York, which allows lumping, provides for lumping; but its California and Pennsylvania forms, where itemization is required, provide for itemization without reservation. See copies on file in Yale Law Library. 
to FTC cease and desist orders. ${ }^{27}$ While the FTC intends to leave local consumer protection to states with equivalent disclosure laws, 28 automobile installment sales in other states will be under the Commission's surveillance.90

The FTC regulations' reach does not promise effective protection for installment buyers. Under its governing Congressional statute, the Commission's jurisdiction extends only to transactions in "interstate commerce." 30 The Federal Trade Commission Act's comparatively slight control over "local" practices may still permit a host of abuses to flourish. The rules, for example, may not apply when a local seller extends installment credit to a local consumer, or where the installment contract is assigned to a local finance company or any bank. ${ }^{31}$ And even for transactions "in" interstate commerce, the Commission's scant enforcement staff cannot stalk a horde of violations. 32 Moreover, private enforcement is stymied by holdings that the Federal Trade Commission Act grants injured consumers no private cause of action against violators. ${ }^{33}$ Even if future decisions spelled out implied private remedies from

27. Under 52 Stat. 112 (1938), 15 U.S.C. $\$ 45$ (b) (1946). Noncompliance with cease and desist orders after they become final is subject to a civil penalty of $\$ 5,000$ for each day of disobedience. 64 STAT. 21 (1950), 15 U.S.C.A. $\$ 45(1)$ (1951).

28. I.e., states listed supra note 17. See FTC "Auto Pacle" Rules In/crpretcd, supra note 24 , at 36-7: "When instances of probable violation are brought to the attention of the Commission in respect of which ... the Federal Trade Commission Act is applieable, reference for state attention shall be made when the state in which the transaction occurs has legislation applicable to the practices and when ... the same or similar requirements are imposed by it as by the rules."

29. Comarunication from FTC Chairaman; FTC "Anto Pack" Rules Imserpreicd, supra note 24 , at 35,37 .

30. Id. at 34-5. See also note 35 infra. For the statutory language, sce nute 24 supra. "Commerce" is judicially defined as "interstate commerce." Chas. A. Brewer \& Sons v. Federal Trade Commission, 158 F.2d 74 (6th Cir. 1946). Under the Act, the Commission has no power over "intrastate" activities even though they affect "interstate commerce." See Federal Trade Commission r. Bunte Bros., 312 U.S. 349 (1941); United States v. Piuma, 40 F. Supp. 119 (D. Cal. 1941) ; Bunn, The National Law of Unfair Compstition, 62 HARv. L. Rev. 987, 989 (1949). Cf. the broader intrastate reach of the Sherman Act, Mandeville Island Farms v. American Crystal Sugar Co., 334 U.S. 219, 234 (1945) ("effects" test). For the apparently narrower test under the Robinson-Patman Act, sce Standard Oil Co. v. Federal Trade Commission, 340 U.S. 231, 237-S (1951).

31. "When the charges relate exclusively or primarily to a motor vehicle financing practice of a bank, such matters will be referred to the appropriate state or federal banking authorities, since banks are exempt from the Federal Trade Commission Act and therefore are not amenable to the rules." Communication from FTC Chainsas. Sce also footnote to the Statement by the Commission preceding the RuLES, 16 FEr. REG. 1059 (1951).

32. Comanunication from FTC Chatrisan.

33. See, e.g., Samson Crane Co. v. Union National Sales, Inc., 87 F. Supp 218 (D. Miass. 1949); aff'd mem. 180 F.2d S96 (1st Cir. 1950). See further Bunn, Thic National Law of Unfair Competition, 62 Hanv. L. Rev. 987, 990 (1947); Rowe, Priec Discriminsotion, Competition, and Confusion, 60 Yale L. J. 929, 974 n. 284 (1951); Note, Fcderol Jurisdiction in Sutts for Danages under Statutes Not Affording Stch Remedy, 48 Cow. L. REv. 1090 (1948). 
the Act's provisions, installment plan consumers might gain cold comfort: comparatively minor amounts involved, together with the small purchaser's lack of funds and ignorance of legal rights make private litigation seem unlikely. ${ }^{34}$ In fact, the FTC recognizes that where state law does not control the problem, consumers for their protection must fall back largely on voluntary compliance and "the elevating influence of the moral and ethical forces among businessmen." 35 And prospects for stepped-up state controls seem dim. ${ }^{30}$

Even where enforced, the FTC's disclosure mandate may not safeguard consumers. Timely and itemized disclosure of credit and insurance charges might stimulate installment buyers to compare the cost of money lonns from credit agencies unaffiliated with finance companies or auto dealers. ${ }^{\mathbf{j 7}}$ Since states clamp ceilings on interest rates for money loans, consumers would probably save by shifting their patronage to regulated money lenders, permitting the purchase of goods with borrowed funds often repayable on an installment basis. ${ }^{38}$ In this way competitive forces in the money-lending market could eventually drive down the cost of installment sales. ${ }^{30}$ The FTC rules,

34. See Mors, sipra note 1, at 209. For discussions of implied private remedies under statutes not expressly conferring them, see sources in note 33 supra.

35. Communication from FTC Champman. See also FTC "Aluto Pack" Rules Iiterpreted, supra note 24 , at 35.

In an effort to secure moral, if not legal commitment to abide by its rules, the FrC has requested some 75,000 recipients of copies of the rules to sign "compliance cards" and place their willingness to cooperate on record with the Commission. Id. at 34. But finance companies doing largely an "intrastate" business are invited to strike out portions of the cards to limit their moral commitment to "such of our business as is in commerce." Id. at 35. "By signing the cards . . one does not divest himself of any of his legal rights or otherwise subject himself to the imposition of any restrictions not imposed by existing law." Communication from FTC Chatrman.

36. See, e.g., the reaction of Texas: "Whereas, the Federal Trade Commission has prescribed rules [requiring presale disclosure], [i]t is the intention of this Act to prescrvo to the seller his legal right to sell motor vehicles on a time credit price and at the samc time permit him to make disclosure to the purchaser... [Disclosure] shall not in any way affect the validity of the whole or any part of the time credit price, nor in any manucr change the legal nature of the time credit contract." TEx. Stat. ANN. tit. 79, art. 5074a, $\$ \$ 1,2$ (Vernon's 1951 Supp.) (emphasis added). And see Micr. Stat. ANv. \$9.1482 (1951 Supp.) (repealing requirement of pre-sale itemization of insurance and finance charges in sale of motor vehicles).

But see ConN. REv. Gen. Stat. \$§1222b, 1223b, 6699(b) (1951 Supp.) (lumping provision recently amended to require pre-sale itemization).

As to the modification of Regulation $W$ in favor of lumping, see note 23 supra.

37. Outstanding retail credit is usually five times greater than outstanding cash loans, despite borrower protection by usury statutes in the latter field. See Mors, supro note 1, at 200. See also Wisconsin ReP0RT 30-2.

38. See note 1 supra. For a case where a seller unsuccessfully attempted to cvade money credit controls by disguising the transaction as a time-sale of an automobile, sce Nazarium v. Lincoln Finance Corp., 78 A.2d 7 (R.I. 1951).

39. "It naturally follows that when the purchaser is made aware of the amount of finance charge and the cost of insurance separately, he is then in a position to 'shop' the 
however, do not press hard for this result. Finance charges need only be disclosed as a dollar amount. But unless charges are expressed in equivalent annual interest rates, consumers cannot easily compare the costs of installment sales and money loans. ${ }^{40}$ Comparison is hampered, moreover, by a prevalent practice of money lenders-disguising the true cost of installment loans by stating interest as though the entire principal were outstanding during the life of the loan. ${ }^{41}$ And not only may consumers be reluctant to overcome inertia and inhibitions against making money loan inquiries, but also the social taint frequently attaching to personal borrowing deters prospective buyers from weighing this alternative form of financing. ${ }^{2}$ Nor will disclosure of a "packed" finance charge galvanize all consumers into competitive shopping, since many installment buyers may not recognize an exorbitant overcharge even when it is disclosed. ${ }^{13}$ Finally, disclosure rules cannot benefit the many installment buyers who do not read or comprehend complex conditional sales agreements. ${ }^{41}$

Absent effective competition between installment sales and money credit markets, only outright state control of installment charges can provide consumer protection. Outlawing the finance companies" practice of "licl:baclis"

seller's competitors with a view to taking advantage of the lowest charges offered. This condition would certainly have a tendency to promote competition, both in the ficld of financing and in the insurance field." Comarumicamox frosi FTC Cuarmar. It is not clear whether the "seller's competitors" referred to are only those in the retail sale credit field or those in money or cash credit as well. But if retail credit sellers alone are meant, the FTC's pre-sale itemization requirement is useless, for buyers cuuld compare lumped charges as easily as itemized charges. Lumping only prevents comparison of retail credit and money credit costs.

40. See Mors, supra note 1, at 212-S; WISconsin Reforr 40-1; Leyislaliun, 63 HAnv. L. REv. $874,877 \mathrm{n} .27$ (1950). None of the state statutes requiring disclosure of marliup items require the finance charge to be stated as an equivalent annual interest rate. See notes 17,18 supra. In fact Maryland requires that it be stated as a dollar sum. 2.50. Axi:. Code Gen. Laws art. 83, \$117(a) (9) (Cum. Supp. 1947). The statutes of New Yorl and Ohio permit statement of finance charges as either equivalent annual interest or dollar sums. N.I. Pers. Prop. Law $\S 64 a(h)$; Ohro Cone \$6346-18 (Page's 1951 Supp.) (if not over 8\%).

Stating the cost of finance in terms of interest can also be deceptive, if the rate does not reflect declining balances. See Ford Motor Company v. Federal Trade Commission, 120 F.2d 175 (6th Cir. 1941) ("6\% Plan" in reality disguising $11 / 2 \%$ simple interest). See note 41 infra.

41. See Collins, Ezasion and Avoidance of Usury Lan's, 8 LAw \& Contrasp. Pron. 54, 56 (1941). See further BAckaran, op. cit. supra note 1, at 4-5.

42. See Mors, supra note 1 , at 201-2.

43. See WISCONSIN REPORT 40.

44. One solution suggested to overcome the "poor reading habits" of consumers is the adoption of standard contract forms for retail sale credit, paralleling those in the insurance field. "[W]ithout reading the contract, the consumer scon becomes acquainted with the details because of his own experience and [that] of his friends." Harric, TuE. Ixstaliment Crenit Contract 22 (1939), quoted by Mors, supra note 1, at 60. 
to dealers might conceivably spark retail credit competition that would benefit consumers: companies presently competing for trade by dealer rebates presumably would channel competition into rate reductions. ${ }^{45}$ But in the context of the automobile market, competition may prove wholly ineffective. A few finance companies tied to the major manufacturers dominate the field ;0 and franchised dealers in the past have been coerced to discount consumer

45. "To get credit prices down to the consumer necessitates easing retail dealer pressure on financing agencies for ever increasing financial concessions . . . By getting directly at this pressure, rate control and kick-back control may actually operate to increatse rather than to decrease the effectiveness of (price) competition in retail instalment fintulcing." Mors, supra note 1 , at 59.

An alternative to such controls on rebates would be disclosure of the rebate as well as markup items. See Wisconsin RePoRr 60. But it is doubtful whether consumers, who may not understand finance charges, see note 40 supra, will comprehend the significance and economics of dealer participation in finance charges. See Note, 60 YALE L. J. 1218 (1951). The Trade Practice Conference held before adoption of the FTC's rules, sce notc 24 supra, discussed controls on dealer participations and rebates. See Press Relcase, ibid. Although the rules develaped from this conference do not expressly deal with the subject, the Commission has intimated that abusive dealer rebates might violate RuLk: 4. Sce compilation of excerpts from the Commission's replies to questions, accompanying ComMUNication from FTC Chairaran.

46. See FTC, Report on Motor Vehicle Industry 921-2 (1939); Cavers, The Collstmer's Stake in the Finance Company Code Controversy, 2 Law \& CONTENIr. Prow. 200, 201-2 (1935). See further Moss, Salcs Finance Company Opcration in 1947, 34 FEv, REs. Buld. 781 (1948); Note, 60 Y ALE L. J. 1218, 1219 n. 5. (1951).

On the basis of their relationship to automobile manufacturers, finance companies are classified as (1) factory-controlled, (2) factory-preferred, and (3) non-factory-related or independent. Finance companies which control the field, General Motors Acceptance Corporation, Commercial Credit Co., Commercial Investment Trust Corporation, with its subsidiary Universal Credit Corporation, have been placed in the first two categories. Sce FTC REPORT, op. cit. sipra, at 921-2. In 1938 the federal government took steps to scparate these finance companies from affiliated manufacturers under the Sherman Act. Chrysler and Ford took consent decrees, see Chrysler Corporation v. United States, 316 U.S. 556 (1942), modified CCH Trade REg. Rep. \ 62,221 (N.D. Ind. 1948) and Ford Motor Co. v. United States, 335 U.S. 303 (1948), while General Motors resisted and lost in a criminal action. United States v. General Motors Corp., 121 F.2d 376 (7th Cir. 1941), cerl. denicd, 314 U.S. 618, rehearing denied, 314 U.S. 710 (1941). Decrees against Chrysler and Ford were conditional upon a final order within a specified period requiring Gencral Motors to divest itself of all interest in its financial subsidiary, GMAC. The Government did not obtain a final order within the period, although numerous extensions were allowed. Ford appealed from the sixth extension, whereupon the Supreme Court lifted, until identical terms are imposed on General Motors, the decree's prohibition against affiliating with, recommending, endorsing, or advertising any finance company. Ford Motor Company v. United States, 335 U.S. 303, 320 (1948). Chrysler obtained similar relaxations of its consent decree by motion on March 29, 1949. See Communication to Yale LAw Journat from Clerk, U.S. District Court of Indiana, dated March 31, 1952, on file in Yale Law Library. As gutted, the decrees still stand against Ford and Chrysler pending outcome of the government's dormant severance suit against General Motors and GMAC, Civil Action No. 2177, in the District Court of the United States, Northern District of Illinois, filed October 4, 1940, complaint amended June 21, 1941. 
installment paper exclusively with the manufacturer's financing affiliate. ${ }^{\text {st }}$ But even if financing companies competitively lowered credit charges, dealers rather than consumers might reap the gain. New-car dealers with exclusive territorial franchises are largely insulated from competitive forces. And competition among used-car dealers is not effective since customers cannot compare and evaluate the different products on the market. Direct controls of installment charges, analogous to present regulation of money lending, may therefore have to supplant disclosure and competition to safeguard consumers from abuse in installment selling. 48

47. United States v. General Mrotors Corporation, 121 F.2d 376 (7th Cir. 1941); ef. Emich Motors Corp. v. General Motors Corp., 340 U.S. 558 (1951), Note, 61 YALE L. J. 417 (1952); and see cases cited note 46 sipra.

Cf. Justice Black's dissent in the Supreme Court's decision relaxing the Ford consent decree: "Hereafter dealers and retail purchasers cannot depend on competiton to keep interest rates at a fair level. Their sole hope for low interest rates and loans on liberal terms will be the spontaneous generosity of Ford, General Mrotors, and Chrysler." Ford Motor Co. v. United States, 335 U.S. 303, 328 (1948).

48. "Public interest demands that such a purchaser have as much protection thrown around him as if he were a borrower." Wisconsin Repont 25. See note 2 supra. Disclosure would still be desirable, even with all-out rate controls: "Even with a ceiling on rates, it may be possible to conceal a limited 'pack' unless ... the contract contains a separate listing of finance and insurance charges." B.ckMsax, op. cit. sipra note 1, at $6 \mathrm{n.2}$.

As to factors to be considered in fixing finance charges, see WIsco:ssis REront 50: "[W] low as to prevent capital from entering the consumer credit field. Otherwise, competition will be stifled, and interest rates instead of decreasing will increase. Furthermore, there is grave danger when finance charges and interest rates are too low of driving the smaller individual companies out of business and turning such business over to the national companies ... It should be further realized that a small item of consumer credit entails as much detail as a large extension of credit in a bank . . Finance companies must keep a large reserve of cash on hand, and the cost of money has to be considered as a factor in the business." See further Note, 60 Y ALE L. J. 1218, 1225 n. 24, 1226-7 (1951). Cf. Upton, The Economics of Fair Charges for Consumer Loans, 16 MIo. L. REv. 274 (1951). And see Hawaii's statutory control, note 23 supra. 